\title{
Changes in land cover to reduce erosion and peak discharge of sub-watershed of Danau Limau Manis
}

\author{
Taufika Ophiyandri ${ }^{1}$, Bambang Istijono ${ }^{1 *}$, Teguh Haria Aditia Putra $^{2}$, Aprisal $^{3}$, and Benny Hidayat $^{1}$ \\ ${ }^{1}$ Department of Civil Engineering, Andalas University, Indonesia \\ ${ }^{2}$ Doctoral Program, Andalas University, Indonesia \\ ${ }^{3}$ Department of Soil Science, Andalas University, Indonesia
}

\begin{abstract}
Land cover change is a strategic issue in the Subwatershed of Danau Limau Manis. The community was triggered by the big earthquake of September 30, 2009, so people moved to the upper watershed. The problem is the increasing number of people, the damage to the watershed ecosystem. This damage can be seen from the erosion of river water and the availability of river water during the rainy season and dry season. An appropriate solution is needed to reduce erosion by modeling land cover. This study aims to determine the value of soil erosion and peak discharge. Erosion using a rational formula using the modified universal soil loss equation model based on land units and peak discharge. The land unit is an overlay of land cover maps, slope maps, and soil maps. Land units that produce erosion and exceed the tolerance limit are carried out with a land cover change scenario using the spatial multi-criteria analysis model. Scenario determination is also based on slope maps, land cover maps, soil maps, river flow density maps, forest area maps, erosion values, and the Padang city spatial plan. The study results explain that the erosion and peak discharge resulting from the existing land cover is quite large, namely 47.89 tons/hectares/year and $152.81 \mathrm{~m} 3 / \mathrm{sec}$. After scenario modeling, erosion decreased by 11.91 tons/hectares/year and peak discharge $15.26 \mathrm{~m} 3 / \mathrm{sec}$.
\end{abstract}

\section{Introduction}

Watershed is seen as an area with a high integration between human interests in meeting the needs of life and the interests of ecosystem protection. This condition often causes problems for the environment. Where one side of the fulfillment of the needs of life that is done by the community often destroys the order of the ecosystem. The destruction of a watershed ecosystem is undoubtedly a big problem that will cause natural disasters, such as floods, landslides, and erosion.

The destruction of the watershed area is in line with the increasing number of people who need land for the built area. The destruction is due to the change in the vegetated land cover into built-up areas, resulting in erosion, sedimentation, and even on a large scale, therefore causing floods, landslides, and flash floods. Changes in land use into built-up areas will impact changes in flow characteristics, flooding in the rainy season, decreasing river discharge, and drought in the dry season [1].

The increasing population also occurs in the Subwatershed of Danau Limau Manis (DLM). This increase was driven by the occurrence of a huge earthquake in 2009 in the city of Padang. The impact of the earthquake prompted coastal communities to move to tsunami-safe locations. One of them is the sub-watershed of DLM in the middle. The threat of a megathrust earthquake that triggers a tsunami wave is still scary news among the public. This condition also encourages people to move to safer locations. So the subwatershed of DLM in the middle is experiencing high population pressure.

The increase in population has led to an increase in residential areas in the Subwatershed of DLM. Currently, the construction of residential areas has led to the upper watershed, which significantly affects the hydrology of the watershed area. The upper watershed of the DLM area, which is part of the Kuranji watershed, also converts forest land into agricultural land. In the Kuranji watershed, forest land cover decreased by $1,128.42$ hectares $(8.52 \%)$, and residential areas increased by $2,577.08$ hectares $(63.10 \%)$ [2]. In the Subwatershed of DLM, forest land cover decreased by 231.56 hectares (7.44\%) and increased residential areas by 49.97 hectares (91.09\%).

Judging from the condition of the slopes, the 50\% wider Subwatershed of DLM has land with a high slope. This condition is hazardous if land cover changes are not appropriately controlled. The high slope conditions are also supported by high rainfall in the Subwatershed of DLM. This causes high runoff, increased soil erosion, and river discharge.

\footnotetext{
* Corresponding Author: bistijono@eng.unand.ac.id
} 
Subwatershed of DLM also has high river density, which impacts high surface runoff and low infiltration. Subwatershed characteristics of DLM produce considerable erosion. This is caused by low soil infiltration and high surface flow, and the potential for landslides. This condition results in a large river discharge and the potential for flooding [3].

The problem in the Subwatershed of DLM can also be seen from the high fluctuation of river discharge during the rainy and dry seasons. The high fluctuation of river discharge indicates that the upper watershed area has begun to experience disturbances in vegetation land cover. Where vegetation should be able to reduce erosion and runoff so that infiltration increases. Increased infiltration makes groundwater reserves increase, and during the winter season, groundwater can fill river water. Based on the current Subwatershed of the DLM problem, the right solution is needed to restore the watershed area and keep it sustainable so that sustainability is maintained. Efforts are being made to optimize land cover in the upstream and middle areas of the Subwatershed of DLM.

This research has two objectives. First, calculate the erosion value based on land units and calculate the peak discharge. Second, the rational method will optimize land cover by predicting erosion using the Modified Universal Soil Loss Equation (MUSLE) and peak discharge. Next, a multi-criteria analysis (SMCA) spatial analysis was carried out to optimize land cover.

\section{Research Significance}

Changes in land cover Subwatershed of DLM is a current problem. The high rate of population growth is an indicator of land cover change. The high population encourages people to use the land for agriculture. This agricultural activity triggers illegal logging in this subwatershed, even in protected forest areas. The conversion of mixed garden lands on relatively steep slopes and paddy fields also occurs. This condition results in high erosion and high fluctuations in river discharge, reaching $191.83 \mathrm{~m} 3 / \mathrm{second}$. In the rainy season, the river discharge reaches a discharge of $409.94 \mathrm{~m} 3 / \mathrm{second}$ with a high sediment concentration. In the dry season, the river discharge is shallow at $2.45 \mathrm{~m} 3 / \mathrm{second}$. Based on these problems, it is necessary to find an appropriate land cover model to reduce erosion and flood discharge.

\section{Materials and Method}

\subsection{Research Location}

The Subwatershed of DLM is administratively located in Padang City, West Sumatra Province. More details can be seen in Fig. 1.

Geographically, the Subwatershed of DLM is bordered to the north by the Subwatershed of Kuranji, the south by the Batang Arau watershed, and the east by the Indragiri watershed. Astronomically is located between $100^{0} 26^{\prime} 24.74 " \mathrm{E}$ - 10033'10.96" E and 0051'23.93" S -
$0^{0} 55^{\prime} 17.79 " \mathrm{~S}$, has a maximum height of $1,865.75$ meters above sea level.

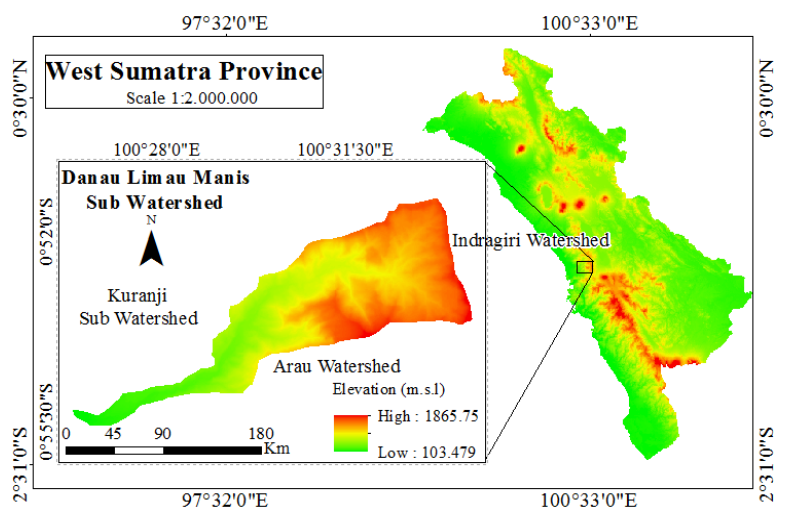

Fig. 1. Research location

\subsection{Materials}

The MUSLE model uses the highest daily rainfall in the last ten years, namely from 2009-2018 at $97.75 \mathrm{~mm} /$ day. Determination of peak discharge using the rational method.

The land cover map consists of forests (Fr), mixed gardens $(\mathrm{Mg})$, rice fields $(\mathrm{Rf})$, shrubs $(\mathrm{Sc})$, and settlements (Sl). The land cover map is sourced from SAS Planet satellite imagery analysis released by Arc-GIS Imagery in 2018. This map uses a spatial resolution of 20x20 meters.

Soil sampling for the MUSLE model analysis used the land unit approach. The land unit map consists of a land cover map, a slope map, and a soil type map.

The scale of the soil map is 1:250,000 consisting of Entisols (Ent) and Inceptisols (Ept). The slope map was analyzed using a DEM map with a resolution of $8 \times 8$ meters. It consists of gentle (B), slightly steep (C), steep (D), and very steep (E). See Fig. 2.

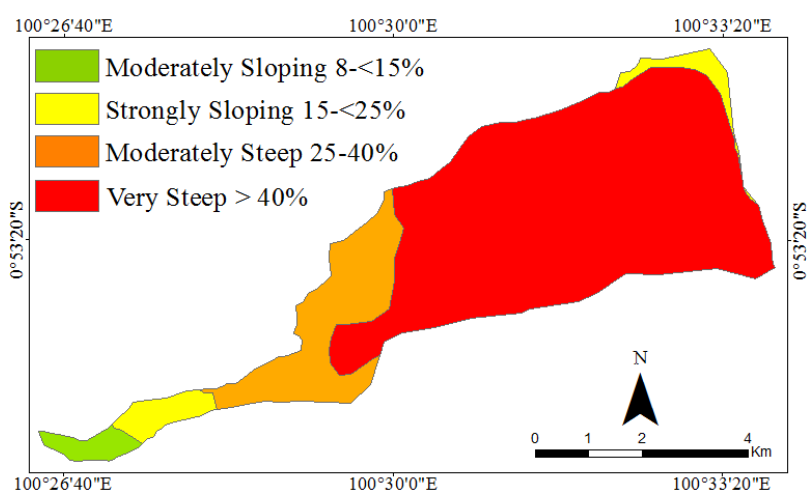

Fig. 2. Slope conditions in the DLM Sub Watershed

\subsection{Method}

The MUSLE equation with the formula:

$$
\mathrm{Sed}^{\prime}=11,8\left(\mathrm{Q}_{\text {surf }} \mathrm{X} \mathrm{q}_{p e a k}\right)^{0,56} \times K \times \operatorname{LS} \times C \times P
$$


Table 1. Soil erosion DLM Sub Watershed

\begin{tabular}{|c|c|c|c|c|c|c|}
\hline $\begin{array}{c}\text { No. } \\
\text { LU }\end{array}$ & \multicolumn{1}{|c|}{ LU } & $\mathbf{R M}$ & $\mathbf{K}$ & $\mathbf{L S}$ & $\mathbf{C P}$ & $\mathbf{E}$ \\
\hline 4 & Ept-B-S1 & 49245.56 & 0.15 & 4.41 & 1 & 10.29 \\
\hline 5 & Ept-B-Mg & 33836.57 & 0.11 & 5.55 & 0.2 & 1.33 \\
\hline 7 & Ept-C-Rf & 66341.94 & 0.18 & 9.45 & 0.02 & 0.70 \\
\hline 8 & Ept-C-Rf & 65649.19 & 0.07 & 7.57 & 0.005 & 0.05 \\
\hline 9 & Ept-C-S1 & 56563.47 & 0.15 & 6.52 & 1 & 17.81 \\
\hline 11 & Ept-C-Mg & 47828.28 & 0.18 & 5.87 & 0.2 & 3.26 \\
\hline 12 & Ept-D-Sc & 40838.80 & 0.13 & 9.45 & 0.3 & 4.82 \\
\hline 13 & Ept-D-Fr & 168572.20 & 0.07 & 18.62 & 0.001 & 0.07 \\
\hline 14 & $\begin{array}{c}\text { Ept-D- } \\
\text { Mg }\end{array}$ & 92315.84 & 0.12 & 10.37 & 0.2 & 7.17 \\
\hline 15 & Ept-E-Fr & 464755.51 & 0.06 & 20.10 & 0.001 & 0.17 \\
\hline 16 & Ept-E-Sc & 6060.51 & 0.20 & 18.24 & 0.3 & 2.15 \\
\hline 22 & Ept-B-Rf & 56159.76 & 0.14 & 5.55 & 0.004 & 0.06 \\
\hline
\end{tabular}

$\mathrm{Lu}$ is a land unit. $\mathrm{RM}$ is the erosivity of rain obtained from surface runoff and peak discharge. $\mathrm{K}$ is the value of soil erodibility, and LS is the value of the slope's

Length and slope. CP is the value of soil conservation measures. $\mathrm{E}$ is the erosion value of tons/hectares/year.

The surface flow equation uses the SCS (Soil Conservation Service) curve number $(\mathrm{CN})$ method with the formula:

$$
\begin{aligned}
& Q \operatorname{surf}=\left((R d a y-0.2 S)^{\wedge} 2\right) /((\text { Rday }+0.8 S)) \\
& S=25.4100 / C N-10
\end{aligned}
$$

Calculating the peak discharge using the rational method with the formula:

$$
\begin{aligned}
& \text { q peak }=0,277 \text { C.I.A } \\
& I=R / 25 \times(24 / \mathrm{Tc})^{2 / 3} \\
& \mathrm{Tc}=\left(0,869 \times \mathrm{L}^{3}\right)^{0,385} / \mathrm{H}
\end{aligned}
$$

The optimization scenario model uses the SMCA model. There are five scenarios of land cover change in this study, where scenario 0 is the existing state. Scenarios 1-4 are based on the SMCA model using an overlay analysis technique of several criteria: slope maps, land cover maps, soil maps, river flow density maps, forest area maps, erosion values, and the Padang City Spatial Plan 2010-2030. Overley analysis was carried out for each map to determine the scenario model of land cover change. An analysis of the erosion value and morphometric characteristics of Subwatershed of DLM was also carried out. After that, the appropriate land cover can be determined in the area. Based on the data used, the only land cover was changed, while the other criteria remained.

\section{Result and Discussion}

\subsection{Erosion}

The subwatershed of DLM consists of 12 land units with an area of 3,158.90 hectares. In this subwatershed, there is one land unit whose erosion value exceeds the erosion tolerance, namely in sample 9 (Ept-C-Sl) of 17.81 tons/hectares/year. The high erosion is because the area is a residential area with a rather steep slope. Land units with low erosion values are found in sample 8 (Ept-C-Frs) of 0.05 tons/hectares/year. Although the RM value and land unit area of sample 8 are larger than sample 9, they do not increase erosion in sample 8 . This is because this land unit is a forest area that has smaller $\mathrm{K}$ and $\mathrm{CP}$ values. Zema [4] explains that forest vegetation can reduce $45 \%$ of the total rainfall that falls on watershed areas. More details can be seen in Table 1 .

Based on soil conditions, sample 9 has a clay texture with a clay percentage of $76.02 \%$. Soil conditions with a dominant texture of clay coupled with a high rainfall intensity of $97.75 \mathrm{~mm} /$ hour impact low infiltration and high runoff. High runoff coupled with steep slope conditions will impact the strength of surface runoff in eroding the soil surface, resulting in significant erosion. Li [5] explained that erosion occurs due to runoff, and erosion increases as the slope conditions get steeper. Liu [6] added that increased rainfall and slope resulted in runoff and erosion increasing rapidly and getting bigger.

The volume weight (BV) value in sample 9 (Ept-C-Sl) is high at $1.29 \mathrm{~g} / \mathrm{cm} 3$. The high density of the soil is also caused by the very low soil organic matter, which is $1.15 \%$. The density has an impact on the soil pores. The higher the density of the soil, result the lower the pore space of the soil. The low soil pore space will result in small infiltration and impact high runoff and erosion. The overall erosion value in the Subwatershed of DLM is 47.89 tons/hectares/year.

The organic matter with a high percentage is found in forest land units with an average of $12.25 \%$. Zeng [7] added that organic matter can improve soil aggregates so that the soil is not easily eroded. It is also added by Anderson [8] that the level of infiltration is positively correlated with soil organic matter. The more the amount of organic matter in the soil, the infiltration will increase. The high content of soil organic matter can give the shape of irregular aggregate pores, and this makes the infiltration bigger [9].

\subsection{Land Cover Change Scenarios}

The scenario model for the Subwatershed of DLM uses the SMCA model based on the erosion value of the land unit. The value of erosion on the land unit is the basis for optimizing land cover, whether it exceeds the erosion tolerance or has a relatively high erosion so that the amount of erosion and runoff can be reduced. 
Scenario determination also looks at the status of protected and conservation forest areas or other use areas (APL). The scenario of the land unit being reforested if it is in a protected and conserved forest area. If it is in the APL area, it is directed to be a mixed garden and settlement.

The slope of the land is also a reference in determining residential areas. Cultivation areas located on slopes above $15 \%$ are used as mixed gardens and below $15 \%$ can be used as residential areas. Consideration of the designation of residential areas is also based on the Regional Regulation of the City of Padang No. 10 of 2011, which states the development of Padang City is directed to the east. Van Haaren [10] explained that GISbased SCMA could assess large geographic areas and display the results on a map. Adiat [11] adds that the GISbased spatial model in analyzing decision-making can be done very accurately and can be trusted if the criteria used are coherent. Vogdrup-Schmidt [12] explained that the model multi-criteria spatial in showing the most suitable area in analysis decision-making. For more details, the scenario for the Subwatershed of DLM is described below.

Subwatershed of DLM has an area of 3,158.90 ha consisting of forest land cover of $91.25 \%$, mixed gardens of $3.92 \%$, shrubs $0.60 \%$, rice fields $2.5 \%$, and settlements of $1.74 \%$. With the condition of the existing land cover, erosion of 47.89 tons/hectares/year. The high erosion in this area is caused by high rainfall, conversion of forest land in the upper watershed, residential areas, and the weak application of soil and water conservation techniques. This land cover condition also produces high surface runoff and peak discharge of 1,456,209.33 m3 and $152.81 \mathrm{~m} 3 / \mathrm{sec}$.

Scenario 1 explains that there are shrubs in the Subwatershed of DLM due to illegal logging in conservation and protected areas with 102.89 hectares. This disturbed area produces high erosion of 14.14 tons/hectares/year. The forest area at this location should produce an average erosion of 0.10 tons/hectares/year; for more details, see Fig. 3.

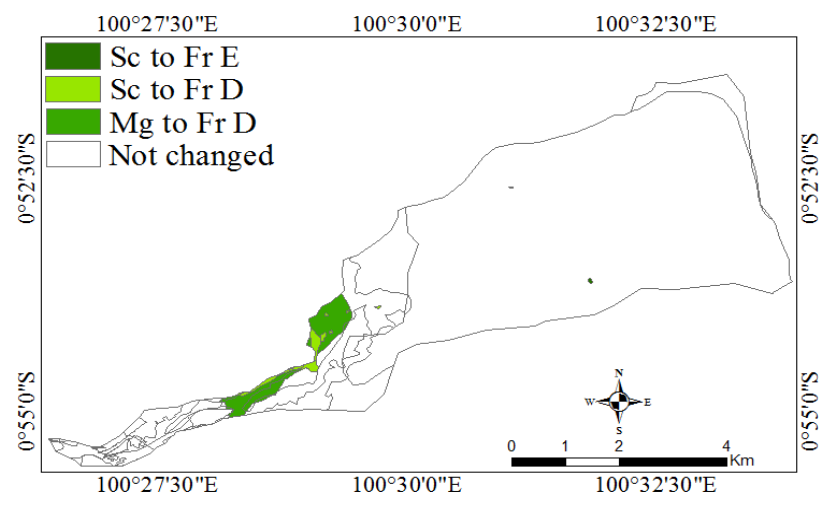

Fig. 3. Scenario 1 land cover change

The location of this area is on a steep slope. This condition causes erosion and runoff that occurs quite large due to the unprotected soil from the kinetic energy of rainfall. So that when it rains, soil particles are easily destroyed by the kinetic energy of rainfall and make it compressed so that it can clog the soil pores. If the soil pores are clogged, then infiltration is reduced, and surface runoff is increased. Impacted by the steep slope conditions, the surface runoff energy increases when transporting eroded soil particles. The mixed garden land cover was also found in protected forest areas of 83.98 hectares and resulted in erosion of 7.17 tons/hectares/year. This location is on a steep slope. If this condition is left unchecked, it will cause the land to be degraded and increase critical land in the upstream subwatershed. Based on this, this location must be reforested. Tadesse [13] explained that increasing vegetation cover by $88 \%$ of the total area could reduce erosion by 4.80 tons/hectares/year.

Scenario 2 explains that in the downstream Subwatershed of DLM, mixed gardens are found on gentle to slightly steep slopes with an area of 39.94 hectares. The resulting erosion was 4.39 tons/hectares/year. This erosion is reduced by increasing the density of mixed gardens because this location is in the middle part of the subwatershed DLM, affecting erosion and surface runoff, increasing river discharge, and leading to flooding in the downstream watershed.

This condition is also hazardous because the Subwatershed has a high river density. When it rains, the surface runoff will quickly enter the river body carrying soil particles. If this condition is left unchecked, it will result in more significant erosion and runoff, leading to landslides, floods, and flash floods. Therefore, the density of mixed gardens needs to be increased. Based on the morphometric characteristics of the Subwatershed of DLM it does not allow land with low vegetation density.

The texture of the soil also influences the high erosion and runoff in the subwatershed. High clay content ranging from $71.17 \%-86.23 \%$. High clay content will reduce infiltration into the soil, especially soils with low vegetation density. The high volume of soil weight also influences erosion that occurs. The heavier the volume of the soil, the denser the soil will be and the less pore space the soil will have.

If these conditions are combined (there are shrubs, exillegal logging and low mixed garden density, steep slopes, high river density, and high rainfall), this condition will cause erosion, large runoff, and low infiltration. So that when it rains, surface runoff and soil particles will quickly enter the river and quickly increase sediment and river discharge. This condition makes the river discharge erode the river channel, thus potentially producing floods and flash floods.

The subwatershed also has dendritic river branches. River branches spread in all parts of the subwatershed and can produce large river discharges. This subwatershed also has a high river density, steep slopes in the upstream and middle, and rather steep at the outlet of the subwatershed. It has an extensive river gradient where the upstream has an average height of $1,747 \mathrm{~m}$ above sea level, and the outlet is $112 \mathrm{~m}$ above sea level with a distance of $17.50 \mathrm{~km}$.

Based on these conditions, it can be explained that high river density will make surface runoff quickly enter the river and reduce the opportunity for water to enter the ground. The steep slope of the land further increases the 
flow velocity of surface runoff, which can wash away more significant amounts of soil particles into the river. The large river gradient causes the rapid flow of the river downstream of the watershed. The rapid flow of this river has the potential to erode the river channel. This can cause extensive erosion, runoff that can erode and carry large amounts of soil particles and even cause landslides. This condition will result in flooding and flash floods. For details, see Fig. 4.

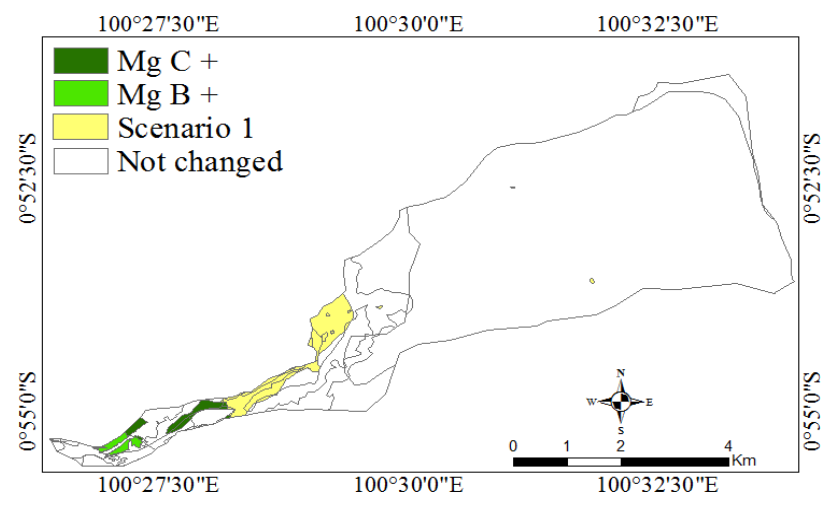

Fig. 4. Scenario 2 land cover change

Scenario 3 emphasizes increasing residential areas. This increase in residential areas needs to be done because the high population growth rate reached $2.83 \%$. Population's need for residential is rising, and the right location is sought for the need. Handavu [14] states that increasing population growth will increase residential areas. The increase in residential areas is limited to the slope factor where the area with a rather steep to the very steep slope is very high, which is $3,084.75$ hectares or $97.65 \%$. In comparison, the area of land with a tiny slope is 74.15 hectares or $2.35 \%$. The increase in residential areas can be done on slope B. The small area of land with gentle slopes makes a choice for residential areas very limited. The only option is to turn the mixed garden into a settlement. This condition will reduce the water catchment area in the Subwatershed of DLM.

In addition, the condition of the upstream area with high river density causes reduced infiltration so that the supply of groundwater decreases during the dry season. However, the erosion produced at this location is low, with a land area of 13.99 hectares.

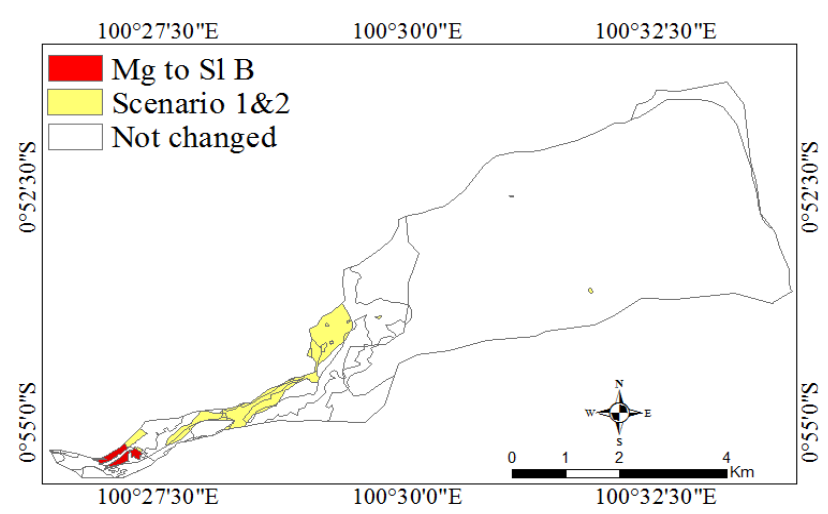

Fig. 5. Scenario 3 land cover change
The improvement of residential areas is carried out by applying soil and water conservation principles, one of which is by making soil pores in open residential areas. Soil pores serve to reduce runoff and increase the supply of water into the soil. For details, see Fig. 5.

In scenario 4, an attempt was made to increase the residential area on a mixed C-slope garden. However, it is not recommended because it is located on a rather steep slope and produces significant erosion of 16.65 tons/hectares/year. For details, see Fig. 6.

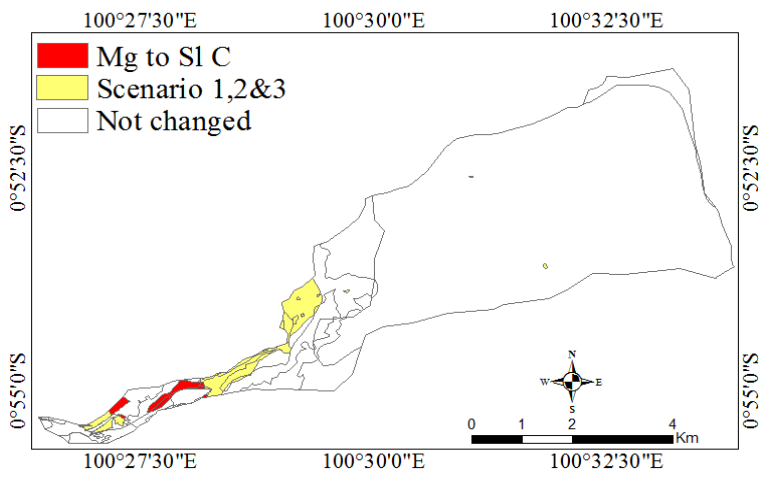

Fig. 6. Scenario 4 land cover change

This condition will have an impact on flooding in the downstream area. For this reason, an optimal scenario is needed so that the Subwatershed of DLM can be utilized optimally without damaging the quality of the environment. The scenario approach used for the subwatershed is based on the land unit's erosion value, which is the basis for optimizing land cover.

\subsubsection{Erosion value based on land cover change scenario}

Scenario 0 is the erosion value in the existing state. The resulting erosion was 47.89 tons/hectares/year. For more details, see Table 2 .

Table 2. Erosion value based on land cover change scenario

\begin{tabular}{|c|c|c|c|c|c|c|}
\hline \multirow[b]{2}{*}{$\begin{array}{l}\text { No. } \\
\text { LU }\end{array}$} & \multirow[b]{2}{*}{ Lu } & \multicolumn{5}{|c|}{ Erosion (tons/hectares/year) } \\
\hline & & $\begin{array}{c}\text { Scen- } \\
\text { ario } \\
0\end{array}$ & $\begin{array}{c}\text { Scen- } \\
\text { ario } \\
1\end{array}$ & $\begin{array}{c}\text { Scen- } \\
\text { ario } \\
2\end{array}$ & $\begin{array}{c}\text { Scen- } \\
\text { ario } \\
3\end{array}$ & $\begin{array}{c}\text { Scen- } \\
\text { ario } \\
4\end{array}$ \\
\hline 4 & Ept-B-Sl & 10.29 & 9.83 & 9.63 & 9.70 & 9.77 \\
\hline 5 & Ept-B-Mg & 1.33 & 1.27 & 0.62 & 6.74 & 6.79 \\
\hline 7 & Ept-C-Rf & 0.70 & 0.67 & 0.66 & 0.66 & 0.67 \\
\hline 8 & Ept-C-Rf & 0.05 & 0.05 & 0.05 & 0.05 & 0.05 \\
\hline 9 & Ept-C-S1 & 17.81 & 17.01 & 16.67 & 16.79 & 16.92 \\
\hline 11 & Ept-C-Mg & 3.26 & 3.12 & 1.53 & 1.54 & 16.65 \\
\hline 12 & Ept-D-Sc & 4.82 & 0.06 & 0.06 & 0.06 & 0.06 \\
\hline 13 & Ept-D-Fr & 0.07 & 0.07 & 0.07 & 0.07 & 0.07 \\
\hline 14 & Ept-D-Mg & 7.17 & 0.13 & 0.13 & 0.13 & 0.13 \\
\hline 15 & Ept-E-Fr & 0.17 & 0.17 & 0.16 & 0.16 & 0.16 \\
\hline 16 & Ept-E-Sc & 2.15 & 0.02 & 0.02 & 0.02 & 0.03 \\
\hline 22 & Ept-B-Sl & 0.06 & 0.05 & 0.05 & 0.05 & 0.05 \\
\hline & Total & 47.89 & 31.79 & 29.64 & 35.98 & 51.35 \\
\hline
\end{tabular}


In scenario 1, the land cover changes from shrubs to a forest in conservation and protected areas in samples 12 and 16. The original erosion from 4.82 and 2.15 tons/hectares/year changed to 0.06 and 0.02 tons/year. Hectares/year. Mixed gardens in a protected area of 83.98 hectares were also converted into the forest. The resulting erosion from 7.17 tons/hectares/year decreased to 0.13 tons/hectares/year or decreased by $98.19 \%$. The total erosion produced in scenario 1 was 31.79 tons/hectares/year or decreased by $33.62 \%$ from scenario 0 .

Scenario 2 is a continuation of scenario 1 . However, in scenario 2, additional scenarios are carried out, namely the mixed gardens in sulfur B and C (samples 5 and 11) are increased in density. The resulting erosion was 1.33 and 3.26 tons/hectares/year to 0.62 and 1.53 tons/hectares/year, respectively. In scenario 2 , the erosion is 29.64 tons/hectares/year or a decrease of $38.11 \%$.

Scenario 3 is a continuation of scenarios 1 and 2 . The addition is to change the sulfur mixture garden B (sample 5) into a settlement. Erosion resulted from 1.33 to 6.74 tons/hectares/year, or an increase of $80.27 \%$. In scenario 3 , erosion of 35.98 tons/hectares/year is generated or decreased by $24.87 \%$ from scenario 0 .

Scenario 4 is also a continuation of the previous scenario. The difference is in sample no 11 by changing the mixed garden slope $\mathrm{C}$ into a settlement. The resulting erosion was 3.26 tons/hectares/year to 16.65 tons/hectares/year, an increase of $80.42 \%$. In scenario 4 , the erosion is 51.35 tons/hectares/year or an increase of $6.73 \%$ from scenario 0 .

Scenario 2 produces a lower erosion value than the other scenarios. This scenario can reduce erosion by 18.25 tons/hectares/year or $38.11 \%$. The disadvantage of this scenario is that it does not provide space for an increase in residential areas. The optimal scenario is in scenario 3 . Where in this scenario, it provides space to increase the settlement area of 13.99 hectares. This scenario can reduce erosion by 11.91 tons/hectares/year or $24.87 \%$ compared to the existing erosion.

The increase in the settlement area on the Subwatershed of DLM can only be done on slope B. If it is increased on slope $\mathrm{C}$, the resulting erosion will be substantial, more than 16.65 tons/hectares/year. From the morphometric conditions, increasing the settlement area on slopes above $15 \%$ is not recommended. It is due to the Subwatershed of DLM having a very high river density, large river gradient. This condition causes surface runoff that transports soil particles to enter the river and drastically increases river discharge quickly. This also results in erosion of river channels, resulting in floods, landslides, and even flash floods.

It can be concluded that the increase in a residential area can be done on slope $\mathrm{B}$ by changing the mixed garden. This change can be made if the need for residential areas is urgently needed. Because this location is located in the downstream Subwatershed of DLM and the middle part of the Kuranji watershed, the increase in residential areas is combined with the creation of pore holes.

\subsubsection{Peak discharge}

Calculation of peak discharge using a rational formula. Where $A(\mathrm{~km} 2)$ is in the area of the subwatershed, I ( $\mathrm{mm} /$ hour) is the intensity of rain, Tc (hour) is the concentration-time, $\mathrm{C}$ is the runoff coefficient, and $\mathrm{Qp}$ $(\mathrm{m} 3 / \mathrm{sec})$ is the peak discharge. More details can be seen in Table 3.

Table 3. Peak discharge existing condition

\begin{tabular}{|c|c|c|c|c|}
\hline $\mathbf{A}$ & $\mathbf{I}$ & $\mathbf{T c}$ & $\mathbf{C}$ & Qp \\
\hline 31.59 & 25.79 & 1.51 & 0.67 & 152.81 \\
\hline
\end{tabular}

The peak discharge of the existing land cover is higher than the other scenarios. The total peak discharge in the existing condition is $152.81 \mathrm{~m} 3 / \mathrm{sec}$. The high peak discharge is caused by many forest land cover being converted into shrubs and community plantations in the upper watershed. The mixed garden land cover also causes the high peak discharge, which is not yet optimal density, on a slope above $15 \%$. For more details on changes in peak discharge based on land cover change scenarios, see Table 4.

Table 4. Peak discharge value based on land cover change scenarios

\begin{tabular}{|c|c|c|}
\hline No & Subwatershed of DLM & Qp ( $\mathbf{m}^{\mathbf{3}} / \mathbf{s e c )}$ \\
\hline 1 & Scenario 0 & 152.81 \\
\hline 2 & Scenario 1 & 135.70 \\
\hline 3 & Scenario 2 & 135.70 \\
\hline 4 & Scenario 3 & 137.55 \\
\hline 5 & Scenario 4 & 139.39 \\
\hline
\end{tabular}

The high peak discharge in existing conditions will cause erosion of river channels and flooding downstream of the watershed. This condition can cause soil damage both physically and chemically. According to Aprisal [15], floods will affect the texture and organic matter of the soil. Flooded land will remove soil organic matter and damage soil structure.

\section{Conclusion}

The existing land cover resulted in erosion and peak discharge of 47.89 tons/hectares/year and $152.81 \mathrm{~m} 3 / \mathrm{sec}$. After the scenario of land cover change scenario, 1 was able to reduce erosion and peak discharge $33.62 \%$ and $11.20 \%$, respectively. Scenario 2 can reduce erosion and peak discharge by $38.11 \%$ and $11.19 \%$. Scenario 3 can reduce erosion and peak discharge by $24.87 \%$ and $9.99 \%$. Scenario 4 increases erosion by $7.22 \%$ and decreases peak discharge by $8.78 \%$.

The optimal scenario is in scenario 3 because it can increase the residential area by 13.99 hectares. This scenario can reduce erosion by 11.91 tons/hectares/year or $24.87 \%$ compared to the existing erosion, with a peak discharge of $137.55 \mathrm{~m} 3 / \mathrm{sec}$. 
We want to express our sincere gratitude to the University of Andalas for the 2021 Research Grant no. T/17/UN16.17/PT01.03/IS-PTU-KRPGB-Unand/2021.

\section{References}

1. R. Permatasari, A. Sabar, D. K. Natakusumah, and H. Samaulah, "Effects Of Watershed Topography And Land Use On Baseflow Hydrology In Upstream Komering South Sumatera, Indonesia," Int. J. GEOMATE, 17, 59, 28-33 (2019).

2. T. H. A. Putra, B. Istijono, Aprisal, B. Rusman, and T. Ophiyandri, "The Dynamics Of Land Cover Change And Causal Factors In The Kuranji Watershed," Int. J. GEOMATE, 21, 84, 69-75 (2021).

3. T. H. A. Putra, B. Istijono, Aprisal, B. Rusman, Andriani, A. Hakam, Adrinal, and T. Ophiyandri, "Interrelations of rainfall and morphometric characteristics in generating geological disasters of Kuranji watershed Padang city," in IOP Conference Series: Earth and Environmental Science, 708, 1 (2021)

4. D. A. Zema, A. E. L. Borja, B .G. Carra, P. Denisi, V. A. Rodrigues, M. Ranzini, F. C. S. Arcova, V. de Cicco, S. M. Zimbone, "Simulating the hydrological response of a small tropical forest watershed (Mata Atlantica, Brazil) by the ANNAGNPS model," Sci. Total Environ., 636, 737-750 (2018).

5. T. Li, S. Li, C. Liang, B. He, and R. T. Bush, "Erosion Vulnerability Of Sandy Clay Loam Soil In Southwest China: Modeling Soil Detachment Capacity By Flume Simulation," Catena, 178, January, 90-99 (2019).

6. Y. Liu, Y. Xin, Y. Xie, and W. Wang, "Effects Of Slope And Rainfall Intensity On Runoff And Soil Erosion From Furrow Diking Under Simulated Rainfall," Catena, 177, 19, 92-100 (2019).

7. Q. Zeng, F. Darboux, C. Man, Z. Zhu, and S. An, "Soil aggregate stability under different rain conditions for three vegetation types on the Loess Plateau (China)," Catena, 167, May, 276-283 (2018).
8. R. L. Anderson, K. R. Brye, and L. S. Wood, "Landuse And Soil Property Effects On Infiltration Into Alfisols In The Lower Mississippi River Valley, USA," Geoderma Reg., 22, e00297 (2020).

9. Y. Zhao, X. Hu, and X. Li, "Analysis Of The IntraAggregate Pore Structures In Three Soil Types Using X-Ray Computed Tomography," Catena, 193, 19, 104622 (2020).

10. R. Van Haaren and V. Fthenakis, "Gis-Based Wind Farm Site Selection Using Spatial Multi-Criteria Analysis (SMCA): Evaluating The Case For New York State," Renew. Sustain. Energy Rev., 15, 7, 3332-3340 (2011).

11. K. A. N. Adiat, M. N. M. Nawawi, and K. Abdullah, "Assessing The Accuracy Of Gis-Based Elementary Multi-Criteria Decision Analysis As A Spatial Prediction Tool - A Case Of Predicting Potential Zones Of Sustainable Groundwater Resources," J. Hydrol., 440-441, 75-89 (2012).

12. M. V. Schmidt, S. B. Olsen, A. Dubgaard, I. T. Kristensen, L. B. Jorgensen, B. Normander, C. Ege, T. Dalgaard, "Using Spatial Multi-Criteria Decision Analysis To Develop New And Sustainable Directions For The Future Use Of Agricultural Land In Denmark," Ecol. Indic., 103, March, 34-42 (2019).

13. L. Tadesse, K. V. Suryabhagavan, G. Sridhar, and G. Legesse, "Land use and land cover changes and Soil erosion in Yezat Watershed, North Western Ethiopia,” Int. Soil Water Conserv. Res., 5, 2, 85-94 (2017).

14. F. Handavu, P. W. C. Chirwa, and S. Syampungani, "Socio-Economic Factors Influencing Land-Use And Land-Cover Changes In The Miombo Woodlands Of The Copperbelt Province In Zambia," For. Policy Econ., 100, October 2018, 75-94 (2019).

15. Aprisal, B. Istijono, T. Ophiyandri, and Nurhamidah, "The Effect Of Flood To Quality Index Of Soil Physical Properties At The Downstream Of Kuranji River Watershed, Padang City," Int. J. GEOMATE, 16, 54, 74-80 (2019) 